\title{
Applying information network analysis to fire-prone landscapes: implications for community resilience
}

\author{
Derric B. Jacobs ${ }^{1}$ and Lori A. Cramer ${ }^{1}$
}

\begin{abstract}
Resilient communities promote trust, have well-developed networks, and can adapt to change. For rural communities in fire-prone landscapes, current resilience strategies may prove insufficient in light of increasing wildfire risks due to climate change. It is argued that, given the complexity of climate change, adaptations are best addressed at local levels where specific social, cultural, political, and economic conditions are matched with local risks and opportunities. Despite the importance of social networks as key attributes of community resilience, research using social network analysis on coupled human and natural systems is scarce. Furthermore, the extent to which local communities in fire-prone areas understand climate change risks, accept the likelihood of potential changes, and have the capacity to develop collaborative mitigation strategies is underexamined, yet these factors are imperative to community resiliency. We apply a social network framework to examine information networks that affect perceptions of wildfire and climate change in Central Oregon. Data were collected using a mailed questionnaire. Analysis focused on the residents' information networks that are used to gain awareness of governmental activities and measures of community social capital. A two-mode network analysis was used to uncover information exchanges. Results suggest that the general public develops perceptions about climate change based on complex social and cultural systems rather than as patrons of scientific inquiry and understanding. It appears that perceptions about climate change itself may not be the limiting factor in these communities' adaptive capacity, but rather how they perceive local risks. We provide a novel methodological approach in understanding rural community adaptation and resilience in fire-prone landscapes and offer a framework for future studies.
\end{abstract}

Key Words: climate change; community-based adaptation; information networks; social capital; wildfire

\section{INTRODUCTION}

Climate change is one of the planet's most distressing and multifaceted phenomena, convoluted with ecological and social complexity (Head 2008, Lazarus 2009, Calpalbo et al. 2010, Perry 2015). Over the past half-century, physical scientists have worked to unravel the ecological causes and consequences of climate change and have developed increased confidence in climate models and forecasting. More recently, scientists have added knowledge on the social dimensions of climate change (Jasanoff 2010, Wynne 2010, Spies et al. 2014). Despite such scientific advances, broad-based policy development to mitigate or halt anthropogenic climate change has been slow in coming (Schneider 2009, Wynne 2010). While global leaders debate the future of climate change policy, climate change impacts are being experienced at local and regional levels (IPCC 2014). To mitigate potential negative climatic impacts, it is critical to assess local adaptation and resiliency capacity. It is anticipated that climate change will impact rural communities in the western United States through potential increases in the number and severity of wildfires (Brunson and Shindler 2004, Dalton et al. 2013, Lui et al. 2013, Spies et al. 2014, Stavros et al. 2014), thereby situating such fireprone places at the nexus of climate change impacts and social impacts.

Recent research concerning adaptive capacity to wildfire focuses on individual values, perceptions of wildfire risk, and motivation for preparedness behavior of private citizens and communities (Wildland Fire Leadership Council 2006, Paveglio et al. 2009, 2016), as well as organization culture and institution budgets (Trego 2012, Spies et al. 2014). Concurrent with the examination of adaptive capacity to climate change is increased incorporation of social vulnerability (Cutter et al. 2008) and resiliency theory to enhance a community's ability to prepare for, respond to, and recover from disruptive events, including wildfire (National Research Council 2006). Resilience in this context is "The capacity of social, economic, and environmental systems to cope with a hazardous event or trend or disturbance, responding or reorganizing in ways that maintain their essential function, identity, and structure, while also maintaining the capacity for adaptation, learning, and transformation" (IPCC 2014:5).

In their review of community resilience literature, Berkes and Ross (2013) analyze theoretical development from social-ecology systems approaches and from psychology and mental health research, and develop an integrated concept of community resilience. An integrated concept of community resilience recognizes the dual benefit of specified and general resilience (Folke et al. 2010). Specified resilience refers to "some particular part of a system" related to a particular control variable or to one or more identified kinds of shocks, whereas general resilience is resilience to any and all parts of a system "to all kinds of shocks, including novel ones" (Folke et al. 2010:22). We argue that community development to assist resilience to wildfires (specified resilience) will provide flexibility for communities to cope with other impacts of climate change (general resilience).

The resilience of coupled social-ecological systems is a shared responsibility among citizens, the private sector, and government (National Research Council 2012). Understanding resilience within a community's diverse and nested social system is critical if public officials and residents are to develop effective adaptation strategies (McLeod and Leslie 2009). If a community can be made more robust, then the recovery time will decrease, and the community will be more resilient. Due to the strong dependence of many rural communities on natural resources for their economic and cultural livelihood, their resilience must include the 
coupled social-ecological systems. To be successful, community resilience needs to emerge through local people within their local social-ecological systems; that is, resilience emerges from the bottom up and reaches toward supportive collaboration with formal governmental institutions (National Research Council 2012). Our work complements that of Abrams et al. (2015), who examined the role of institutional flexibility and organizational integration to enhance community resilience. Our interest is to expand understanding of individual-level decision-making (e.g., bottom-up) as an avenue to strengthening links to organizational structures (e.g., top-down), thereby building overall communitylevel adaptive capacity to climate change impacts.

The resilience of a community to natural and built hazards is inextricably linked to the antecedent conditions associated within the region. Individual and community resilience to change varies depending upon local histories, natural resource dependency, previous experience with change, and availability for support (Brunson and Shindler 2004, Ensor and Berger 2009). Thus, whether a community and its residents can demonstrate future social-ecological resilience depends on complex and multidimensional pre-event contexts. Not all residents within a community or region will be equally resilient due to a variety of socio-cultural factors (Cutter et al. 2003, 2008, Cramer 2015) which may impact the degree of a community's overall resiliency. Consistent with disaster vulnerability, in Oregon, such socio-cultural factors primarily include social class, gender, disability, age, and race (Peacock et al. 1997, Dach-Gruchow and Hong 2006, Dash et al. 2007).

Studies also suggest that local social capital is important for community resilience through collective behaviors that build and sustain cohesion, trust, and action (Adger 2003, Putnam and Feldstein 2004, Ahn and Ostrom 2008, Lin and Erickson 2008, Flora and Flora 2013). Social capital generally refers to the relationships, norms, and benefits derived from social networks. The availability of local social capital - in particular, access to social ties and information networks - allows communities to adapt to change (Paton and Johnston 2001). The availability of social networks as a form of social capital is linked to a community's well-being (Norris et al. 2008, Magis 2010); however, social capital itself is not ubiquitously positive and may be embedded with underlying aspects of conflict, including power relations (Cramer et al. 1991, Satterthwaite 2013, McDougall and Banjade 2015).

Research that examines neighborhood social capital prior to an ecological event, such as wildfire, is scant (Wickes et al. 2015). Social and information networks and communication, reciprocity, trust, collaboration, and feelings of solidarity for the provision of support may be critical in promoting community resilience (Grootaert et al. 2004, Brenkert-Smith et al. 2013, Barnes et al. 2016), specifically to wildfire (Steelman and McCaffrey 2013), as well as climate change adaptation (Adger 2003). We address this research gap and examine residents' current socio-political values and information network systems associated with wildfire and climate change, and the correlation to community trust, collaborative capacity, and solidarity in two Central Oregon communities, which have not been subject to devastating wildfires.
Central Oregon, climate change, and increased fire risk

In Oregon, wildfires are prevalent in the relatively dry forests and rangelands on the eastern side of the Cascade Mountains. As in many other states, wildfires have always been part of the socialecological system. Today, however, public debates regarding what land managers can do about wildfires, and the associated risks, are ubiquitous. Climate change studies and improved modeling indicate that this region could experience conditions that will result in more frequent and severe wildfires (Dalton et al. 2013). Projections on climate change in Central Oregon's ponderosa and lodgepole pine forests, mixed fir forests, open conifer forests, and high sagebrush deserts (Campbell et al. 2003, Creutzburg et al. 2015) show that shorter winters, longer summers, and frequent drought will contribute to more frequent wildfires (Spies et al. 2010, Dalton et al. 2013). The monetary, social, and ecological costs associated with wildfires arise primarily from a combination of encroaching development in the wildland-urban interface and the impacts that forestry practices, especially fire suppression, have had on fuel loads (Pyne 2008, Hammer et al. 2009, Vose et al. 2012). Communities within or near fire-prone forests face numerous risks to life (to residents and firefighters), property and community infrastructure, and resources (Morton et al. 2003, Alig and Mercer 2011, Calkin et al. 2014). Other concerns include the loss of aesthetic and amenity values (Stetler et al. 2010) and the impacts on fish and wildlife, particularly where these are core resources that support traditional cultures, commercial activities, and recreation-related livelihoods (Morton et al. 2003, Morzillo and Alig 2011). In summary, due to the potential for increased environmental hazards, these communities face additional risks and vulnerabilities to their social, political, cultural, and economic conditions (Westerling et al. 2006, Spies et al. 2010, Lal et al. 2011, Wimberly and Liu 2014, U.S. Department of Interior and U.S. Department of Agriculture 2014).

\section{Research framework}

For communities to adapt to climate change, it is advisable that they (1) understand and accept the potential local impacts of climate change, (2) develop and maintain a collective sense of solidarity, and (3) develop and/or maintain collaborative relationships with government and nongovernmental organizations. The first two factors are prudent for community-based adaptive capacity, while the third enhances adaptive capacity by providing resources that are often limited in small communities (Ensor and Berger 2009, Berkes and Ross 2013).

Social capital as a means of understanding how people and communities act and react to climate change is gaining scholarly attention (Aldrich 2012, Aldrich and Meyer 2015). Aldrich (2012:15) claims that social capital is "the core engine of recovery" for communities - even more central to recovery than economic resources, amount of aid money, government response, agency assistance, or level of damage. With the reductions in state and federal resources that are available to rural communities, the role of social capital will be increasingly relied upon for local hazard mitigation and disaster recovery. There is no unified definition or measurement of social capital (Tzanakis 2013). It can include network connections among citizens, and between citizens and institutions, such as the relationship between citizens and government (Bourdieu 1986, Coleman 1988, Szreter and Woolcock 2004). Social capital can be used to assess the value of relationships based on trust and reciprocity to an individual, a 
community, a region, or a country. Social capital, social relationships, and the structure of networks can create valued resources (capital) that can assist in individual and community well-being (Lin 2001, Lin et al. 2001, Burt 2005, Lin and Erickson 2008). Finally, social capital is the advantage given to an individual by his/her position in a social network's structure for access to and use of resources embedded within the network and the overall advantage a group gains from its network structure (Lin 2001, Burt 2005, Lin and Erickson 2008). We use Aldrich's (2012:2) definition of social capital, who describes it simply as "the networks and resources available to people through their connections to others." We aggregate individual-level perceptions of dimensions of social networks (e.g., information sources, governmental trust, and solidarity) to assess overall communitylevel social capital.

Social capital is generally assessed for the outcomes it generates: instrumental outcomes, which provide some status or resource such as wealth, knowledge, or power; or in community-level, expressive outcomes, which cultivate and retain a capacity to increase recovery from shocks and augment the effectiveness of adaptive action, thereby enhancing resiliency (Bourdieu 1986, Harshaw and Tindall 2005, Lin 2008). Instrumental social capital can be studied through theoretical and methodological approaches, such as Ronald Burt's (2005) network "brokerage" and Nan Lin's "prestige index" (Lin et al. 2001). Expressive social capital can include norms and values, and measures of community trust and collaborative potential. In this study, we looked at expressive measures of social capital (governmental trust, community collective action, and community solidarity) (Harshaw and Tindall 2005) and the correlation to residents' perceptions of climate change and their concerns about localized risks. We also inquired into what sources of information on governmental activity residents are using (instrumental social capital) and the correlation these ties have to the expressive social capital measures.

Studies reveal distinct variations in adaptive capacity based on the size and public infrastructure among communities (Vincent 2007, Paveglio et al. 2009, Wickes et al. 2015). As noted by Paveglio et al. (2009), scholars lack knowledge regarding the diversity and variability of people and communities that occupy the areas associated with the wildland-urban interface. Moreover, studies have found that some communities have a greater capacity for mobilizing their collective resources (Flint and Luloff 2005). Understanding the differences in the social context between communities, including demographic and structural characteristics, understanding and acceptance of climate change information, and the informal interactions and relationships residents have with one another is critical to knowing how communities can successfully adapt to climate change and its impact on coupled human and natural systems. We provide a conceptual understanding to help guide social inquiry into changing social structures and their outcomes by comparing questionnaire responses between residents in two communities: La Pine and Greater Crescent, Oregon. We believe that this understanding will assist local residents, natural resource managers, and policymakers in adapting to climate change impacts.

The goals of this study are to (1) assess individual level of concern for local risk of climate change, and (2) use social network analysis to examine climate change information networks and social capital variables for the purpose of guiding and informing efforts for community-based climate change adaptive capacity and community resilience to localized manifestations of climate change. To achieve these goals, we adopt an integrative approach (Berkes and Ross 2013) to address the following research questions:

1. Do measures of expressive social capital within the community correlate to values and beliefs about climate change and concerns about local risks? Perceptions and beliefs about climate change are often associated with worldviews and core values more than scientific literacy. We hypothesized that these worldviews are simultaneously driving residents' perceptions of their social environment and their natural environment, and that measures of expressive social capital can indicate to what degree they are likely to be concerned with an environmental issue such as climate change and related local risks.

2. What are the more commonly used information sources by residents for governmental activities, and is there a distinct difference between the nascent incorporated community and the traditional neighboring rural communities? Studies in social capital and social networks have found that smaller communities promote tighter relationships among residents and that information is more likely to be transmitted within social ties, while information sources in larger communities become impersonal and more reliant on common media (Richardson et al. 1979, Allcott et al. 2007). We hypothesized that social ties are used by residents more for gaining information on governmental activities in smaller rural communities than in the expanding city of La Pine.

3. Is there a correlation between a community's information sources on governmental activities (their instrumental social capital) and the measures of solidarity, collective action potential, and governmental trust (their expressive social capital)? In areas where forests are threatened by increasing wildfire on public lands, information on governmental activities should provide a fundamental tool to intercommunity institutional collaboration. We explore governmental information source types with perceptions of community solidarity, collaborative action potential, and trust in government. We also explore a possible distinction between mass media and localized information sources to perceptions of community, collective action, and solidarity.

\section{Study area}

In the Pacific Northwest, large segments of the forested landscape are titled to the federal government, divided between the U.S. Department of Agriculture's Forest Service (USFS) and the Department of the Interior's Bureau of Land Management (BLM). Roughly $60 \%$ of the land in Oregon is owned by the federal government (most of it with the USFS and BLM), $3 \%$ is owned by the state, and $1 \%$ is owned and managed by other public interest holders (Oregon Department of Forestry 2009). This scale of land ownership and management illustrates the importance and dependence on federal land management agencies and congressional oversight on land management. Many wildfires in Oregon start on federal lands and then become transboundary issues. 
We focus on two communities in central Oregon: the recently incorporated city of La Pine (LP), and the socio-economically interdependent rural communities collectively referred to here as Greater Crescent (GC) (Gilchrist, Crescent, and Crescent Lake). The incorporated area of LP has 1640 residents with a median age of 39.3, while the GC area is home to roughly 1025 residents with a median age of 52.5 (Oregon Explorer 2014, USA.com 2015). In LP, the median household income is $\$ 25,046$, the largest employment sector is in retail trade $(23.7 \%)$, and $14.6 \%$ and $42 \%$ of the population receive retirement and social security, respectively. GC's median income is $\$ 33,350,23.8 \%$ of the population is employed in arts, entertainment, recreation, and accommodation, $30.2 \%$ of the population receives retirement income, and $58.5 \%$ collects social security. These communities are representative of rural communities that are facing similar challenges associated with wildfire risks and adapting to climate change, such as potential risks to human health and lives, loss of property and infrastructure, and impacts on natural and cultural resources. These communities' survival may depend on their resilience in the face of increased wildfire frequency and severity, and their ability to develop effective adaptive strategies.

In addition to their common natural resource dependency, these two communities were selected for their contrasting governance structures. The recent incorporation of LP centralizes public services and signals a shift in socio-political and economic conditions compared to unincorporated rural communities such as those of GC. Centralized city development distances the hub of human activity from adjacent forests and provides residents with a fire department and emergency agencies that are responsible for health and safety. These governance changes may alter LP's risks and vulnerabilities to wildfire and shift the city's adaptive capacity for resiliency within the social structure. Communities in the GC area that are adjacent to the forest depend on county-based law enforcement and a volunteer rural fire district, and have fewer formal institutions that are responsible for emergency management, which possibly makes them more vulnerable. Unlike LP, many of the residential properties in GC (35.1\%) are owned by people who live outside the area and are occupied seasonally for recreation purposes (United States Census Bureau 2015). Gilchrist, Oregon also has one of the last operating timber mills in the region.

\section{METHODS}

The primary methodology used in this study was a mailed questionnaire, based on the iterative mailing strategies defined by Dillman and Smyth (2009), which was sent to all identified owneroccupied residences in the region: 345 households in LP and 338 households in the GC area. Prior to the mailing, an article about the study was published in the local newspaper, and a notice card was sent to the households. The response rate was $23 \%$ for LP and $30 \%$ for GC (Table 1). The relatively low response rate motivated us to conduct a nonresponse phone survey of 25 residents in each community (50 total residents, randomly conducted throughout the day and early evening). A statistical sampling bias check showed no statistical difference between the questionnaire sample and the nonresponse survey samples in either community (Dillman and Smyth 2009).
Table 1. Response rate for mailed questionnaires to all identified owner-occupied residents.

\begin{tabular}{lccc}
\hline \hline & La Pine & Greater Crescent & Total \\
\hline Mailed & 345 & 338 & 683 \\
Returned & $79(23 \%)$ & $102(30 \%)$ & $181(27 \%)$ \\
\hline
\end{tabular}

The mail questionnaire consisted of four sections: (1) community measures of expressive social capital; (2) respondents' perceptions, beliefs, and values related to climate change and wildfire; (3) respondents' social and information networks; and (4) demographic characteristics. The data were analyzed in SPSS 22 software (IBM Corporation 2013), and network data were processed and analyzed with UCINET version 6.512 (Borgatti et al. 2002).

\section{Social capital}

Community-level social capital, as used here, refers to the respondents' overall trust in varying levels of the hierarchal governmental bodies, plus the community's solidarity and willingness to engage in collective action. The first section of the questionnaire used 16 core questions (Appendix 1, Fig. A1.1) about community-level (expressive) social capital. These questions were modeled after Measuring Social Capital: An Integrated Questionnaire (Grootaert et al. 2004) in an effort to capture multiple dimensions of the communities' social capital, such as trust, collective action and cooperation, information and communication, social cohesion and inclusion, empowerment, and political action. We modified the questions to make them locally relevant by adding key words such as "fire," "wildfire," and community names. For example, in Grootaert et al.'s question, "If there was a water supply problem in this community, how likely is it that people will cooperate to try to solve the problem" (Grootaert et al. 2004:47), we changed "water supply" to "fire".

We analyzed the questions using principal component and reliability analysis (Field 2013). The emerging factors were then used as explanatory variables along with the location (community) and control variables of gender and age on the dependent variables of climate change perceptions and on an index of concerns about local risks in hierarchical multiregressions.

\section{Perceptions, beliefs, and values related to climate change and local risks}

Perceptions about climate change were measured on two scales. The first scale assessed a broad global position that measured respondents' perception of climate change on a six-point scale (inspired by Global Warming's Six Americas [Leiserowitz et al. 2012]). At the global scale, we measured answers to the question, "How would you define your position on climate change?" and offered brief statements that outlined a specific opinion for each choice. Respondents could indicate that they were alarmed, concerned, cautious, disengaged, doubtful, or dismissive (Maibach et al. 2009, Leiserowitz et al. 2012). The alarmed opinion was "Climate change is occurring and risks to this region are high." Subsequent statements represented concerned ("Climate change is occurring and risks may be harmful to this region"), cautious ("Climate change is occurring but I am unsure 
of any risks to this region"), disengaged ("I feel there are more important issues to worry about in this region than climate change"), doubtful ("Climate change has not been proven and risks are unknown at this point in time"), and at the end of the scale, the dismissive opinion was an absolute, "Climate change is not real."

The second scale, a more localized position on climate change, measured five items of concern regarding local risks. Using a Likert scale, where " 1 " indicated "not at all concerned" and "4" indicated "strongly concerned," we asked respondents to identify their level of concern about impacts to the local economy, recreation, culture, natural and resources, and impacts from natural disasters or hazards. We analyzed the data from the five items for each community through principal component and reliability analysis and condensed them into a single index labeled "concerns for local risks" (with Cronbach's $\alpha=0.908$ ) for statistical analysis.

\section{Social networks and information sources}

Data were collected on respondents' (instrumental) social capital, including information about their social ties and information sources for climate change and government activities based on the assumption that information on governmental activities carries both direct and indirect effects related to wildfire risk mitigation, emergency response, and post-event rehabilitation. For this study, a list of 14 information source nominations (Appendix 2) were provided to assess where respondents receive information regarding governmental activities, with respondents identifying their three most frequently used sources. Examples of sources included personal/social relationships, local newspapers, and the internet. Items were analyzed using two-mode network analysis, which examined the ties of two distinct types of characters (modes) (Wasserman and Faust 1994, Prell 2012). In this case, the two modes were actors and information sources. Fig. 1 is a two-mode graph generated by UCINET's NETDRAW software. It illustrates the individual residents as circular dots and information sources as blue squares. The normalized degree centrality analysis tool inflates the information sources used most by the residents. As indicated, in LP, the internet, television, and local newspapers emerged as the top sources; in GC, television, local newspapers, and personal and social relationships were the top three information sources.

\section{Demographic information}

The final section of the survey included standard demographic data used in social science studies in the United States. The questions asked respondents to identify their gender, age, ethnicity, education level, work situation, and household income. We also asked respondents about their length of residence in Oregon and in their community. Gender and age offered the best selection for the nonresponse bias analysis and acted as control variables in the regression analyses.

A thorough discussion of the methods used and the analysis of the results is provided in the Appendixes. The methods for the expressive social capital PCA and reliability analysis with hierarchal multiregression analysis with expressive social capital as the independent variables and climate change and concerns abour local risks as the dependent variables are provided in Appendix 2. Appendix 3 presents the information networks on governmental activities and bivariate correlations to expressive social capital measures.
Fig. 1. Two-mode network analysis graph with expressed normalized degree centrality measures for both La Pine (LP) and Greater Crescent (GC). The inflated information source nodes (blue squares) illustrate the top three information sources identified by each community.

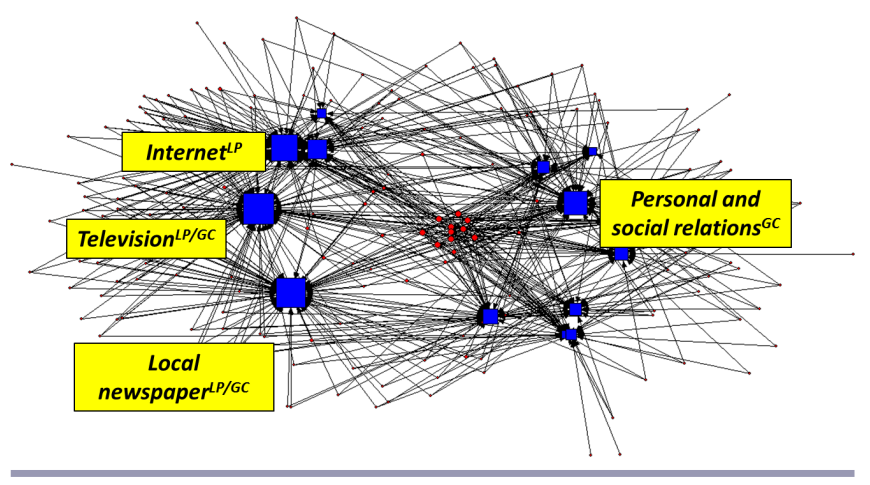

\section{RESULTS}

Climate change and concerns about local risks

Recall that respondents were asked "How would you define your position on climate change?" and could indicate that they were alarmed, concerned, cautious, disengaged, doubtful, or dismissive. No one category received a majority of responses in either community (Table 2). In LP, disengaged received the most responses $(34.8 \%$ ), and dismissive received no responses. In GC, cautious received the most responses $(27.7 \%)$, and similar to LP, dismissive received the least (1.1\%). Resident responses were also compared to those in Leiserowitz et al.'s (2012) Global Warming's Six Americas study. The most noticeable difference between our respondents and those in the Six Americas study is the high percentage of respondents in both LP and GC who were disengaged with the climate change issue $(34.8 \%$ and $23.4 \%$, respectively, versus $6 \%$ in the Six Americas study).

Table 2. La Pine and Greater Crescent's reported perceptions of climate change, along with the 2012 Global Warming's Six Americas study reporting (Leiserowitz et al. 2012).

\begin{tabular}{lcccccc}
\hline \hline & $\begin{array}{c}\text { Alarmed } \\
\text { ned }\end{array}$ & $\begin{array}{c}\text { Concer- } \\
\text { ned }\end{array}$ & \multicolumn{2}{c}{$\begin{array}{c}\text { Cautious } \\
\text { ged }\end{array}$} \\
\hline La Pine & $8.7 \%$ & $15.9 \%$ & $26.1 \%$ & $34.8 \%$ & $14.5 \%$ & $0.0 \%$ \\
Greater & $10.6 \%$ & $20.2 \%$ & $27.7 \%$ & $23.4 \%$ & $17.0 \%$ & $1.1 \%$ \\
Crescent & & & & & & \\
Six & $13.0 \%$ & $26.0 \%$ & $29.0 \%$ & $60.0 \%$ & $15.0 \%$ & $10.0 \%$ \\
Americas & & & & & & \\
\hline
\end{tabular}

Residents were asked about their level of concern regarding potential risks to their region from climate change. Potential risks included those to the economy, recreation, culture, natural resources, and natural hazards. Respondents from the two communities viewed natural resources and natural hazards as areas of highest concern (Table 3). Both communities shared about the same level of concern regarding risks to the local economy, and GC had a slightly higher level of concern about risks to local recreation than did residents of LP. 
Table 3. Response to "To what extent are you concerned about potential negative impacts in [your community] from climate change on the following (local risks)?" Values reflect the percentage of respondents who indicated "high concern" to "unsure."

\begin{tabular}{lccccc}
\hline \hline & High & Moderate & Slight & Low & Unsure \\
\hline 3a. La Pine & & & & & \\
Economy & & & & & \\
Recreation & $13.2 \%$ & $34.0 \%$ & $26.4 \%$ & $22.6 \%$ & $3.8 \%$ \\
Culture & $15.8 \%$ & $25.0 \%$ & $22.4 \%$ & $6.6 \%$ & $0.0 \%$ \\
Natural resources & $5.7 \%$ & $17.0 \%$ & $37.7 \%$ & $35.8 \%$ & $3.8 \%$ \\
Natural hazards & $18.2 \%$ & $34.0 \%$ & $30.2 \%$ & $15.1 \%$ & $1.9 \%$ \\
& $24.5 \%$ & $30.2 \%$ & $30.2 \%$ & $11.8 \%$ & $3.8 \%$ \\
3b. Greater Crescent & & & & & \\
Economy & $16.9 \%$ & $29.9 \%$ & $23.4 \%$ & $15.6 \%$ & $13.0 \%$ \\
Recreation & $22.5 \%$ & $24.5 \%$ & $16.7 \%$ & $8.8 \%$ & $2.9 \%$ \\
Culture & $11.5 \%$ & $26.9 \%$ & $25.6 \%$ & $20.5 \%$ & $14.1 \%$ \\
Natural resources & $28.2 \%$ & $34.6 \%$ & $17.9 \%$ & $10.3 \%$ & $7.7 \%$ \\
Natural hazards & $29.5 \%$ & $28.2 \%$ & $24.4 \%$ & $10.3 \%$ & $6.4 \%$ \\
\hline
\end{tabular}

\section{Social capital and climate change perceptions}

Using PCA with varimax rotation and reliability analysis in SPSS 22 (Field 2013), social capital measures revealed three major components, labeled governmental trust, collective action, and solidarity (Table 4). The governmental trust, collective action, and solidarity indices scored greater than a Cronbach's $\alpha$ of 0.700 , which signified a reliable index based on the identified components (Vaske 2008, Field 2013). Furthermore, removal of any of the questions from the indices did not affect the Cronbach's $\alpha$. All remaining items reflected both statistical and conceptual fits and correlated well with the dimensions of social capital identified by Grootaert et al. (2004).

Hierarchal multiple regressions showed the three components of social capital correlated to the level of concern respondents had for climate change and local risks (Appendix 2). Two of the components, community collective action and community solidarity, were related to concern about local risks, whereas trust in government correlated with climate change positions. This suggests that the more respondents perceive they have collective strength, the more they perceive the local risks of climate change.

The relationship between governmental trust and perceptions of climate change indicates that although climate change is an environmental/scientific phenomenon, respondents' perceptions were possibly influenced by political views. Although political orientation and ideological positions were not directly tested in the research model, previous research identified trust in government as a substantial component of U.S. political orientation. Furthermore, political ideology and orientation are significant contributors to climate change perceptions and beliefs (Marquart-Pyatt et al. 2014, Leiserowitz et al. 2015, Shao 2017). People who subscribe to a more left-leaning political philosophy tend to share both trust in government institutions and acceptance of climate change science; those on the right, tend to be suspicious of government and skeptical of climate science. Here, the more trust residents have in governmental institutions, the more risk and concern they identify with climate change. Interestingly, this factor of social capital was not related to concerns about local risks in the regression analysis.

Solidarity, the third factor, was negatively related to concerns about local risks, though the significance level was not high. For this reason, we removed this variable in the bivariate correlation analysis.

\section{Information sources for governmental activities and trust in government}

Understanding which information sources residents regularly use is important for addressing collective and collaborative efforts to generate adaptive capacity and resilience. From the original list of 14 sources (Appendix 1, Fig. A1.2), network analysis revealed that respondents most frequently used television, the internet, local newspapers, and personal and social relations to gain information about government activities. In GC, television and local newspapers were the primary media sources (normalized centrality scores of 0.431) for gaining knowledge about government activities, and personal and social relations were ranked third (0.353) (Appendix 3). Like their rural neighbors, LP respondents also used their local newspaper and television $(0.468$ and 0.494 , respectively) as their primary information source; however, they reported much less dependence on personal and social relations (0.286) and greater use of the internet (0.429).

For LP, radio and the internet were the only information sources that had statistically significant correlations to governmental trust, and both of these correlations were negative (Appendix 3). The internet (-0.30) was the third most central information type for LP.

The relationships of sources of information to government trust and collective action were different for GC and LP (Appendix 3). In GC, nongovernmental organizations were the only information source correlated to governmental trust $(-0.24)$ and collective action (-0.22). It is noteworthy that nongovernmental organizations were not one of the three most central information types reported in the questionnaire for these communities. Greater Crescent respondents appear to have less trust in government and a lower perception of the community's ability to act collectively and collaboratively.

\section{DISCUSSION}

The overall results of this study suggest that community-based adaptation may best be addressed through increased localized media attention and dialogue between residents and existing formal institutions. Such results are consistent with a community capacity to act on complex issues (Weber 2003, Putnam and Feldstein 2004); however, our results provide evidence that the focus of climate change discussions should be on the localized manifestation (e.g., increased fires) of salient risks (e.g., impacts to natural resources) rather than global impacts of climate change.

Specifically, our analyses revealed a significant correlation among the measures of (expressive) social capital, perception of climate change, and the localized risks climate change may pose to the residents. Furthermore, social capital measures were correlated to the information sources used by respondents. In GC, information obtained from nongovernmental organizations was negatively correlated to both governmental trust and collective action. These results have implications for community-level 
Table 4. Summary of the exploratory principal component analysis and reliability results on social capital questions. Rotation method is Varimax with Kraiser Normalization. Coefficients suppressed with values less than 0.30 and scores greater than 0.40 appear are in bold $(N=159)$.

\begin{tabular}{|c|c|c|c|}
\hline Survey question & Governmental trust & Collective action & Solidarity \\
\hline Oregon state government agencies can be trusted & 0.879 & & \\
\hline Local government agencies can be trusted & 0.870 & & \\
\hline County government agencies can be trusted & 0.841 & & \\
\hline Federal government agencies can be trusted & 0.825 & & \\
\hline $\begin{array}{l}\text { Most people in...would attend public fire education and emergency } \\
\text { preparedness presentations }\end{array}$ & & 0.780 & \\
\hline $\begin{array}{l}\text { If there is a community event to assist people with becoming prepared for } \\
\text { wildfire, most people will participate in some way }\end{array}$ & & 0.736 & \\
\hline The people of...prepare for the unexpected & & 0.651 & \\
\hline Most people in...participate in community activities & & 0.617 & 0.319 \\
\hline $\begin{array}{l}\text { If there is a major fire in or near..., people would come together to solve the } \\
\text { problems }\end{array}$ & & 0.599 & 0.416 \\
\hline ...has a fire preparedness program with information that is readily available & 0.301 & 0.554 & \\
\hline $\begin{array}{l}\text { People in...work together with governmental leaders for the benefit of the } \\
\text { community }\end{array}$ & 0.400 & 0.486 & \\
\hline In..., most people can be trusted & & & 0.841 \\
\hline Most people in....are willing to help if you need it & & 0.377 & 0.667 \\
\hline $\begin{array}{l}\text { In..., you can express different points of view in public conversations without } \\
\text { fear or concern }\end{array}$ & & & 0.573 \\
\hline I feel like I have power and control over my life and property & 0.313 & & 0.568 \\
\hline The people of...have similar values & & 0.345 & 0.513 \\
\hline Eigenvalues & 5.722 & 2.379 & 1.157 \\
\hline$\%$ of variance & 35.763 & 14.871 & 7.233 \\
\hline Kaiser-Meyer-Olkin: 0.844 & & & \\
\hline Cronbach's $\alpha$ & 0.904 & 0.815 & 0.727 \\
\hline
\end{tabular}

resiliency, in particular, their adaptive capacity to act collectively and collaboratively toward localized climate change and wildfire risks. A positive perception of the community's ability to work together strengthens residents' concern about local risks and potentially their willingness to address these risks. Though perceptions of governmental trust strengthened the perception of climate change, it failed to have a relationship to concerns about localized risks. To expand on the analysis here, future research should delve more deeply into previous wildfire experiences and perceptions of formal institutional responses.

Sources of information are important components of social networks. Respondents in our study indicated the use of mass media as important to obtaining information on governmental activities. The use of mass media such as radio and television in rural areas can be problematic because most of the information is not contextually localized due to a reliance on nonlocal media networks. The local newspaper and personal and social relationships, on the other hand, can specify the context of information and provide meaning to both individuals and the community. Although our results found that personal relationships and the local newspaper were used to convey information on governmental activities, they failed to correlate to trust and collaboration either positively or negatively. Increasing discussion points through articles in the local newspaper and online publications is likely to increase discussion through social relations and may encourage more formal interactions and collaborations. The collaborators can negotiate the meaning of localized climate change into a socially valued assessment of the risks.
For residents in areas with significant government landholding, trust is often an important factor for successful collaboration. However, trust is a complex concept, with some studies indicating low agency trust in communities adjacent to natural areas (Krannich and Smith 1998) and others indicating higher trust (Davenport et al. 2007). Wynveen and Sutton (2015) found a relationship between trust and intentions to engage in climate change mitigation behaviors. In the analysis presented here, governmental trust did not statistically correlate to localized concerns about climate change risks. These results are important given the residents' dependency on nearby natural resources. These findings may provide an opportunity for agencies to reach out to the most proximate communities and engage them in management discussions to enhance trust (Lijeblad et al. 2009). It is also important to note that many of the media sources, either central to the community or not, that share a relationship with governmental trust were negatively correlated. This may imply a potential barrier to institutional collaboration, and warrants further investigations on specific media outlets and their rhetoric on government. It may also be prudent to investigate the extent to which localized climate change and wildfire risks in Central Oregon should be intertwined; that is, more attention should be given to the potential for increasing frequency and severity of wildfires rather than a thorough understanding of the factors driving the change (e.g., climate change).

By comparing a recently incorporated community (LP) with a set of traditional rural communities (GC), we were able to provide baseline information on the socio-political and economic functions of rural communities. Consistent with rural places, GC 
indicated personal relationships as primary sources of information more so than LP. Despite shifts in the overall social systems between these communities, the natural systems remain the same. The forest conditions are similar and the expectations of increasing wildfire risks driven in part by climate change are the same based on geographic proximity. Thus, in this case, the coupled human and natural system is potentially affected more by the human or social systems than by the natural system. As fire risks increase due to climate change, the balance of this relationship could shift. The local governance structure (incorporated versus unincorporated) may play a role in how these, and similar rural areas, respond to future climate change risks.

\section{CONCLUSIONS}

This research provided an initial exploration of social capital and information networks as a methodological tool to better understand dimensions of instrumental and expressive forms of social capital in rural regions in fire-prone landscapes. The evidence provided in this study suggests that community-level adaptive capacity for climate change may be limited by perceptions of localized risks rather than an understanding and acceptance of global warming and climate change. Community leaders and natural resource managers, instead of asking local community residents whether or not they believe climate change is a driving factor in wildfire risks in their region, should begin by asking whether or not residents perceive a risk of increased severity and number of wildfires in the near future. Rather than focusing on climate change per se, it may be more salient to focus on climate change actions, such as fire risk management, which will ultimately contribute to overall climate change resiliency. We observed varying levels of potential community-level climate change adaptive capacity in the study area, as measured by concerns about local risks, social capital (government trust, collective action, and solidarity), and residential information networks (information sources regarding government activities). It is not surprising that governmental trust correlates with climate change, given that most available information on the science of climate change for public consumption comes from governmental institutions or institutions that secure and maintain government funding. This finding simply suggests that local governmental institutions are communicating information about climate change. Interestingly, however, governmental trust fails to correlate with concerns about local risks, and this could be because government-reported scientific information on climate changes focuses on global and national scales rather than regional and local scales.

Consistent with our grounding in the literature described herein, information networks likely remain important contextual variables for adaptive capacity, and many of the legitimate scientific efforts to better understand the complexity of climate change and to address its risks to people and social systems are linked in some manner to various levels of government. Governments may not be addressing the potential impacts that residents are likely to see locally, such as increased fire hazards. Our study focused on resident perceptions and connections to information networks; however, future studies examining specific individual and collective adaptive behavior are needed to more fully address the role of information networks as a key component of community resilience.
With projections of increasing wildfire occurrence and severity in the Central Oregon region, it seems that the development of community-based adaptation and collaboration with the federal and state landholders of the region is prudent. Knowing the information preferences for a community should allow for targeted, efficient communication and collaborative campaigns.

Although people and societies have an aptitude for adapting to new systems once they arise, the efficiency of adaptation is often reduced with post hoc policy development and social adaptation. Waiting for the progression of major events to begin development could promote additional costs to the people and infrastructure. Given the uncertainties of United States Congressional action, for both local and global climate mitigation efforts, it behooves residents and agencies to enhance local adaptive capacity by collaboratively addressing resiliency to local risk impacts (e.g., wildfires) that ultimately strengthen resiliency to broader climate change impacts.

Responses to this article can be read online at: http://www.ecologyandsociety.org/issues/responses. $\mathrm{php} / 9119$

\section{Acknowledgments:}

This research was funded by the National Science Foundation's Coupled Human and Natural Systems Program (NSF Grant CHH-1013296) and the USDA Forest Service PNW Research Station.

\section{LITERATURE CITED}

Abrams, J. B., M. Knapp, T. B. Paveglio. A. Ellison, C. Mosely, M. Nielsen-Pincus, and M. Carroll. 2015. Re-envisioning community-wildfire relations in the U.S. West as adaptive governance. Ecology and Society 20(3):34. http://dx.doi. org/10.5751/ES-07848-200334

Adger, W. N. 2003. Social capital, collective action, and adaptation to climate change. Economic Geography 79(4):387404. http://dx.doi.org/10.1111/j.1944-8287.2003.tb00220.x

Ahn, T. K., and E. Ostrom. 2008. Social capital and collective action. Pages 70-100 in D. Castiglione, J. Deth, and G. Wolleb, editors. The handbook of social capital. Oxford University Press, Oxford, UK.

Aldrich, D. P. 2012. Building resilience: social capital in postdisaster recovery. University of Chicago Press, Chicago, Illinois, USA. http://dx.doi.org/10.7208/chicago/9780226012896.001.0001

Aldrich, D. P., and M. A. Meyer. 2015. Social capital and community resilience. American Behavioral Scientist 59(2):254 269. http://dx.doi.org/10.1177/0002764214550299

Alig, R. J., and E. Mercer, editors. 2011. Effects of climate change on natural resources and communities: a compendium of briefing papers. General Technical Report PNW-GTR-837. U.S. Forest Service, Pacific Northwest Research Station, Portland, Oregon, USA. http://dx.doi.org/10.2737/pnw-gtr-837 
Allcott, H., D. Karlan, M. M. Möbius, T. S. Rosenblat, and A. Szeidl. 2007. Community size and network closure. American Economic Review 97(2):80-85. http://dx.doi.org/10.1257/aer.97.2.80

Barnes, M. L., J. Lynham, K. Kalberg, and P. Leung. 2016.Social networks and environmental outcomes. Proceedings of the National Academy of Sciences of the United States of America 113(23):6466-6471. http://dx.doi.org/10.1073/pnas.1523245113

Berkes, F., and H. Ross. 2013. Community resilience: toward an integrated approach. Society and Natural Resources 26:5-20. http://dx.doi.org/10.1080/08941920.2012.736605

Borgatti, S. P., M. G. Everett, and L. C. Freeman. 2002. UCINET 6 for Windows: software for social network analysis. Analytic Technologies, Harvard, Massachusetts, USA.

Bourdieu, P. 1986. The forms of capital. Pages 241-258 in J. Richardson, editor. Handbook of theory and research for the sociology of education. Greenwood, New York, New York, USA.

Brenkert-Smith, H., K. L. Dickinson, P. A. Champ, and N. Flores. 2013. Social amplification of wildfire risks: the role of social interactions and information sources. Risk Analysis 33(5):800817. http://dx.doi.org/10.1111/j.1539-6924.2012.01917.x

Brunson, M. W., and B. A. Shindler. 2004. Geographic variation in social acceptability of wildland fuels management in the Western United States. Society and Natural Resources 17:661-678. http://dx.doi.org/10.1080/08941920490480688

Burt, R. B. 2005. Brokerage and closure: an introduction to social capital. Oxford University Press Inc., New York, New York, USA.

Calkin, D. E., J. D. Cohen, M. A. Finney, and M. P. Thompson. 2014. How risk management can prevent future wildfire disasters in the wildland-urban interface. Proceedings of the National Academy of Science of the United States of America 111(2):746751.

Calpalbo, S., J. Julian, T. Maness, and E. Kelly. 2010. Toward assessing the economic impacts of climate change on Oregon. In K. D. Dello and P. W. Mote, editors. The Oregon climate change assessment report. College of Oceanic and Atmospheric Sciences, Oregon State University, Corvallis, Oregon, USA.

Campbell, S., D. Azuma, and D. Weyermann. 2003. Forests of eastern Oregon: an overview. General Technical Report PNWGTR-578. U.S. Forest Service, Pacific Northwest Research Station, Portland, Oregon, USA. http://dx.doi.org/10.2737/pnwgtr-578

Coleman, J. S. 1988. Social capital in the creation of human capital. American Journal of Sociology 94:S95-S120. http://dx. doi.org/10.1086/228943

Cramer, L. A. 2015. Preparing for the big one: vulnerable populations as key indicators of community resilience. Rural Connections: 9(2):13-16.

Cramer, L. A., P. J. Riley, and G. Kiger. 1991. Support and antagonism in social networks: effects of community and gender. Journal of Social Behavior and Personality 6:991-1005.

Creutzburg, M. K., J. E. Halofsky, J. S. Halofsky, and T. A. Christopher. 2015. Climate change and land management in the rangelands of Central Oregon. Environmental Management 55:43-55. http://dx.doi.org/10.1007/s00267-014-0362-3

Cutter, S. L., L. Barnes, M. Berry, C. Burton, E. Evans, E. Tate, and J. Webb. 2008. Community and regional resilience: perspectives from hazards, disasters and emergency management. Community and Regional Resilience Initiative, Report 1. [online] URL: http:// www.resilientus.org/wp-content/uploads/2013/03/

FINAL CUTTER 9-25-08 1223482309.pdf

Cutter, S. L., B. J. Boruff, and W. L. Shirley. 2003. Social vulnerability to environmental hazards. Social Science Quarterly 84(2):242-261. http://dx.doi.org/10.1111/1540-6237.8402002

Dach-Gruchow, K., and Y. Hong. 2006. The racial divide in response to the aftermath of Katrina: a boundary condition for common ingroup identity model. Analyses of Social Issues and Public Policy 6(1):125-141. http://dx.doi.org/10.1111/ j.1530-2415.2006.00110.x

Dalton, M. M., P. W. Mote, and A. K. Snover. 2013. Climate change and the Northwest: implications for our landscape, waters and communities. Island Press, Washington D.C., USA. http://dx. doi.org/10.5822/978-1-61091-512-0

Dash, N., B. H. Morrow, J. Mainster, and L. Cunningham. 2007. Lasting effects of Hurricane Andrew on a working-class community. Natural Hazards Review 8(1):13-21. http://dx.doi. org/10.1061/(asce)1527-6988(2007)8:1(13)

Davenport, M. A., J. E. Leahy, D. H. Anderson, and P. J. Jakes. 2007. Building trust in natural resource management within local communities: a case study of the Midewin National Tallgrass Prairie. Environmental Management 39:353-368. http://dx.doi. org/10.1007/s00267-006-0016-1

Dillman, D. A., and J. D. Smyth. 2009. Internet, mail, and mixedmode surveys: the tailored design method. Wiley and Sons, Hoboken, New Jersey, USA.

Ensor, J., and R. Berger, editors. 2009. Understanding climate change adaptation: lessons from community-based approaches. Practical Action Publishing Ltd., Warwickshire, UK. http://dx. doi.org/10.3362/9781780440415

Field, A. 2013. Discovering statistics using IBM SPSS statistics. Fourth edition. SAGE Publishing Ltd., Thousand Oaks, California, USA.

Flint, C. G., and A. E. Luloff. 2005. Natural resource-based communities, risk, and disaster: an intersection of theories. Society and Natural Resources 18:399-412. http://dx.doi. org/10.1080/08941920590924747

Flora, C. B., and J. L. Flora. 2013. Rural communities: legacy and change. Fourth edition. Westview Press, Boulder, Colorado, USA.

Folke, C., S. R. Carpenter, B. Walker, M. Scheffer, T. Chapin, and J. Rockstrom. 2010. Resilience thinking: integrating resilience, adaptability and transformability. Ecology and Society 15(4):20. http://dx.doi.org/10.5751/es-03610-150420

Grootaert, C., D. Narayan, V. N. Jones, and M. Woolcock. 2004. Measuring social capital: an integrated questionnaire. World Bank, Washington, D.C., USA. http://dx.doi.org/10.1596/0-8213-5661-5 
Hammer, R. B., S. I. Stewart, and V. C. Radcliff. 2009. Demographic trends, the wildland-urban interface, and wildfire management. Society and Natural Resources 22:777-782. http:// dx.doi.org/10.1080/08941920802714042

Harshaw, H. W., and D. B. Tindall. 2005. Social structure, identities, and values: a network approach to understanding people's relationships to forests. Journal of Leisure Research 37 (4):426-449.

Head, B. W. 2008. Wicked problems in public policy. Public Policy 3(2):101-118.

IBM Corporation. 2013. IBM SPSS statistics for Windows. Version 22.0. IBM, Armonk, New York, USA.

Intergovernmental Panel on Climate Change (IPCC). 2014. Summary for policymakers. Pages 1-32 in C.B. Vields, V. Barros, D. J. Dokken, K. J. Mach, M. D. Mastrandrea, T. E. Bilir, M. Chatterjee, K. L. Ebi, Y. O. Estrada, R. C. Genova, B. Girma, E. S. Kissel, A. N. Levy, and S. MacKraken, editors. Climate change 2014: impacts, adaptation, and vulnerability. Contribution of Working Group II to the Fifth Assessment Report of the Intergovernmental Panel on Climate Change. Cambridge University Press, New York, New York, USA.

Jasanoff, S. 2010. A new climate for society. Theory, Culture \& Society 27(2-3):233-253. http://dx.doi.org/10.1177/0263276409361497

Krannich, R. S., and M. D. Smith. 1998. Local perceptions of public lands natural resource management in the rural West: toward improved understanding of the "revolt in the West." Society and Natural Resources 11:677-695. http://dx.doi. org/10.1080/08941929809381111

Lal, P., J. R. R. Alvalapati, and E. D. Mercer. 2011. Socioeconomic impacts of climate change on rural United States. Mitigation and Adaptation Strategies for Global Change 16:819844. http://dx.doi.org/10.1007/s11027-011-9295-9

Lazarus, R. J. 2009. Super wicked problems and climate change: restraining the present to liberate the future. Cornell Law Review 94(3):1153-1234.

Leiserowitz, A., E. Maibach, C. Roser-Renouf, G. Feinberg, and S. Rosethal. 2015. Politics \& global warming, Fall 2015. Yale University and George Mason University, New Haven Connecticut, USA. [online] URL: http://climatecommunication. yale.edu/wp-content/uploads/2016/01/Politics-and-Global-WarmingFall-2015-2.pdf

Leiserowitz, A., E. Maibach, C. Roser-Renouf, and J. Hmielowski. 2012. Global warming's Six Americas in March 2012 and November 2011. Yale Project on Climate Change Communication, Yale University and George Mason University, New Haven, Connecticut, USA. [online] URL: http:// climatecommunication.yale.edu/publications/global-warmings-sixamericas-in-march-2012-and-november-2011/

Lijeblad, A., W. T. Borrie, and A. E. Watson. 2009. Determinants of trust for public lands: fire and fuels management on the Bitterroot National Forest. Environmental Management 43:571584. http://dx.doi.org/10.1007/s00267-008-9230-3

Lin, N. 2001. Social capital: a theory of social structure and action. Cambridge University Press, New York, New York, USA. http:// dx.doi.org/10.1017/cbo9780511815447
Lin, N. 2008. A network theory of social capital. In D. Castiglione, J. W. Van Deth, and G. Wolleb, editors. The handbook of social capital. Oxford University Press Inc., New York, New York, USA.

Lin, N., K. Cook, and R. S. Burt, editors. 2001. Social capital: theory andresearch. Transaction Publishers, New Brunswick, New Jersey, USA.

Lin, N., and B. H. Erickson. 2008. Social capital: an international research program. Oxford University Press Inc., New York, New York, USA. http://dx.doi.org/10.1093/acprof:oso/9780199234387.001.0001

Lui, Y., S. L. Goodrick, and J. A. Stanturf. 2013. Future U.S. wildfire potential trends projected using a dynamically downscaled climate change scenario. Forest Ecology and Management 294:120-135. http://dx.doi.org/10.1016/j.foreco.2012.06.049

Magis, K. 2010. Community resilience: an indicator of social sustainability. Society and Natural Resources 23:401-416. http:// dx.doi.org/10.1080/08941920903305674

Maibach, E., C. Roser-Renouf, and A. Leiserowitz. 2009. Global warming's six Americas 2009: an audience segmentation analysis. Yale Project on Climate Change Communication, Yale University and George Mason University, New Haven, Connecticut, USA. [online] URL: http://trid.trb.org/view.aspx?id=889822

Marquart-Pyatt, S. T., A. M. McCright, T. Dietz, and R. E. Dunlap. 2014. Politics eclipses climate extremes for climate change perceptions. Global Environmental Change 29:246-257. http://dx. doi.org/10.1016/j.gloenvcha.2014.10.004

McDougall, C., and M. R. Banjade. 2015. Social capital, conflict, and adaptive collaborative governance: exploring the dialectic. Ecology and Society 20(1):44. http://dx.doi.org/10.5751/ es-07071-200144

McLeod, K., and H. Leslie. 2009. Ecosystem-based management for the oceans. Island Press, Washington, D.C., USA.

Morton, D. C., M. E. Roessing, A. E. Camp, and M. L. Tyrrell. 2003. Assessing the environmental, social, and economic impacts of wildfire. Yale University School of Forest and Environmental Studies GISF Research Paper 001. [online] URL: http:// interwork.sdsu.edu/fire/resources/documents/AssessingWildfireImpacts. pdf

Morzillo, A. T., and R. J. Alig. 2011. Climate change impacts on wildlife and wildlife habitat. Pages 1-42 in Effects of climate change on natural resources and communities: a compendium of briefing papers. General Technical Report PNW-GTR-837. U.S. Forest Service, Pacific Northwest Research Station,Portland, Oregon, USA.

National Research Council. 2006. Facing hazards and disasters: understanding human dimensions. National Academy Press, Washington, D.C., USA.

National Research Council. 2012. Disaster resilience: a national imperative. National Academy Press, Washington, D.C., USA.

Norris, F. H., S. P. Stevens, B. Pfefferbaum, K. F. Wyche, and R. L. Pfefferbaum. 2008. Community resilience as a metaphor, theory, set of capacities, and strategy for disaster readiness. Journal of Community Psychology 41:127-150. 
Oregon Department of Forestry. 2009. Forest facts: Oregon forests: some facts and figures. [online] URL: https://www.oregon. gov/ODF/Documents/AboutODF/ForestryFactsFigures.pdf

Oregon Explorer. 2014. Rural communities explorer. [online] URL: http://oregonexplorer.info/topics/rural-communities?ptopic $=140$

Paton, D., and D. Johnston. 2001. Disasters and communities: vulnerability, resilience and preparedness. Disaster Prevention and Management: An International Journal 10(4):270-277. http://dx. doi.org/10.1108/eum0000000005930

Paveglio, T. B., J. Abrams, and A. Ellison. 2016. Developing fire adaptive communities: the importance of interactions among elements of local context. Society and Natural Resources 29 (10):1246-1261. http://dx.doi.org/10.1080/08941920.2015.1132351

Paveglio, T. B., J. P. Jakes, M. S. Carroll, and D. R. Williams. 2009. Understanding social complexity within the wildland-urban interface: a new species of human habitation? Environmental Management 43(6):1085-1095. http://dx.doi.org/10.1007/s00267-009-9282$\underline{\mathrm{Z}}$

Peacock, W. G., B. H. Morrow, and H. Gladwin. 1997. Hurricane Andrew: ethnicity, gender, and the sociology of disasters. International Hurricane Center, Miami, Florida, USA.

Perry, J. 2015. Climate change adaptation in the world's best places: a wicked problem in need of immediate attention. Landscapes and Urban Planning 133:1-11. http://dx.doi. org/10.1016/j.landurbplan.2014.08.013

Prell, C. 2012. Social network analysis: history, theory and methodology. Sage Publications Ltd., Thousand Oaks, California, USA.

Putnam, R. D., and L. Feldstein. 2004. Better together: restoring the American community. Simon and Schuster, New York, New York, USA.

Pyne, S. J. 2008. Spark and sprawl: a world tour. Forest History Today Fall(2008):4-10.

Richardson, R. J., B. H. Erickson, and T. A. Nosanchuk. 1979. Community size, network structure, and the flow of information. Canadian Journal of Sociology 4(4):379-392. http://dx.doi. org/10.2307/3340260

Satterthwaite, D. 2013. The political underpinnings of cities' accumulated resilience to climate change. Environment and Urbanization 25(2):381-391. http://dx.doi.org/10.1177/0956247813500902

Schneider, S. H. 2009. Science as a contact sport: inside the battle to save Earth's climate. National Geographic, Des Moines, Iowa, USA.

Shao, W. 2017. Weather, climate, politics, or God? Determinants of American public opinions toward global warming. Environmental Politics 26(1):71-96. http://dx.doi. org/10.1080/09644016.2016.1223190

Spies, T. A., T. W. Giesen, F. J. Swanson, J. F. Franklin, D. Lach, and K. N. Johnson. 2010. Climate change adaptation strategies for federal forests of the Pacific Northwest, USA: ecological, policy, and socio-economic perspectives. Landscape Ecology 25:1185-1199. http://dx.doi.org/10.1007/s10980-010-9483-0
Spies, T. A., E. M. White, J. D. Kline, A. P. Fisher, A. Ager, J. Bailey, J. Bolte, J. Koch, E. Platt, C. S. Olsen, D. Jacobs, B. Schindler, M. M. Steen-Adams, and R. Hammer. 2014. Examining fire-prone forest landscapes as coupled human and natural systems. Ecology and Society 19(3):9. http://dx.doi. org/10.5751/es-06584-190309

Stavros, E. N., J. T. Abatzoglou, D. McKenzie, and N. K. Larkin. 2014. Regional projections of the likelihood of very large wildland fires under a changing climate in the contiguous Western United States. Climatic Change 126(3):455-468. http://dx.doi.org/10.1007/ s10584-014-1229-6

Steelman, T. A., and S. McCaffrey. 2013. Best practices in risk and crisis communication: implications for natural hazards management. Natural Hazards 65:683-705. http://dx.doi. org/10.1007/s11069-012-0386-Z

Stetler, K. M., T. J. Venn, and D. E. Calkin. 2010. The effects of wildfire and environmental amenities on property values in northwest Montana, USA. Ecological Economics 69:2233-2243. http://dx.doi.org/10.1016/j.ecolecon.2010.06.009

Szreter, S., and M. Woolcock. 2004. Health by association? Social capital, social theory, and the political economy of public health. International Journal of Epidemiology 33(4):650-667. http://dx. doi.org/10.1093/ije/dyh013

Trego, G. D. 2012. We didn't start the fire....and we won't pay to stop it: financing wildfire management in America's wildlandurban interface. William and Mary Environmental Law and Policy Review 36:595-634.

Tzanakis, M. 2013. Social capital in Bourdieu's, Coleman's and Putnam's theory: empirical evidence and emergent measurement issues. Educate 13(2):2-23.

United States Census Bureau. 2015. [online] URL: http://www. census.gov/

United States Department of Interior and U.S. Department of Agriculture. 2014. The National Strategy: the final phase in the development of the National Cohesive Wildland Fire Management Strategy. Washington, D.C., USA. [online] URL: http://www.doi. gov/news/upload/20140328 CSPhaseIIINationalStrategy SurnameCopy execSec FINAL v3.pdf

USA.com. 2015. [online] URL: http://www.usa.com/oregonstate.htm

Vaske, J. J. 2008. Survey research and analysis: applications in park, recreation and human dimensions. Venture Publishing, Inc., State College, Pennsylvania, USA.

Vincent, K. 2007. Uncertainty in adaptive capacity and the importance of scale. Global Environmental Change 17(1):12-24. http://dx.doi.org/10.1016/j.gloenvcha.2006.11.009

Vose, J. M., D. L. Peterson, and T. Patel-Weynand. 2012. Effects of climate variability and change on forest ecosystems: a comprehensive science synthesis for the U.S. . General Technical Report PNW-GTR-870. U.S. Forest Service, Portland, Oregon, USA. [online] URL: http://www.srs.fs.usda.gov/pubs/42610

Wasserman, S., and K. Faust. 1994. Social network analysis: methods and applications. Cambridge University Press, New York, New York, USA. 
Webber, E. P. 2003. Bringing society back in: grassroots ecosystem management, accountability, and sustainable communities. MIT Press, Cambridge, Massachusetts, USA.

Westerling, A. L., H. G. Hidalgo, D. R. Cayan, and T. W. Swetnam. 2006. Warming and earlier spring increase western U. S. forest wildfire activity. Science 313:940-943. http://dx.doi. org/10.1126/science.1128834

Wickes, R., R. Zahnow, M. Taylor, and A. R. Piquero. 2015. Neighborhood structure, social capital, and community resilience: longitudinal evidence from the 2011 Brisbane flood disaster. Social Science Quarterly 96(2):330-353. http://dx.doi. org/10.1111/ssqu. 12144

Wildland Fire Leadership Council. 2006. A collaborative approach for reducing wildland fire risks to communities and the environment: 10-year Strategy Implementation Plan. [online] URL: https:// www.forestsandrangelands.gov/resources/plan/documents/10yearstrategyfinal dec2006.pdf

Wimberly, M. C., and Z. Liu. 2014. Interactions of climate, fire and management in future forests of the Pacific Northwest. Forest Ecology and Management 327:270-279. http://dx.doi.org/10.1016/ j.forec0.2013.09.043

Wynne, B. 2010. Strange weather, again: climate science as political art. Theory, Culture \& Society 27(2-3):289-305. http:// dx.doi.org/10.1177/0263276410361499

Wynveen, C. J., and S. G. Sutton. 2015. Engaging the public in climate change-related pro-environmental behaviors to protect coral reefs: the role of public trust in the management agency. Marine Policy 53:131-140. http://dx.doi.org/10.1016/j.marpol.2014.10.030 
Appendix 1: Questions for Community social capital and roaster of governmental information sources.

Figure A1.1: The 16 questions for measuring community social capital (from the La Pine questionnaire).

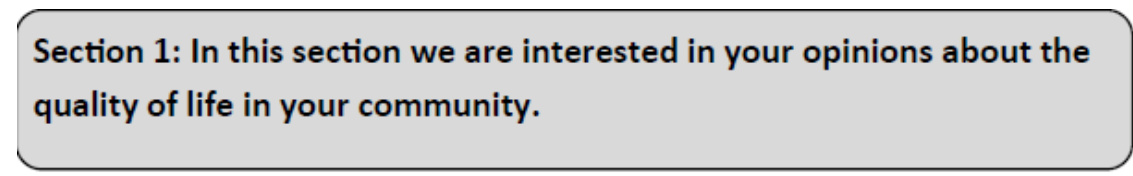

Q1. To what extent do you agree or disagree with these statements?

(Please check the circle that best represents your opinion)

Most people in La Pine are willing to help if you need it.

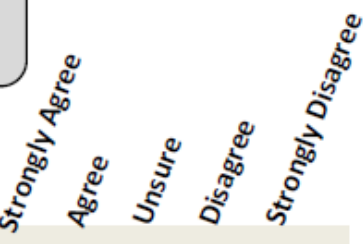

In La Pine, most people can be trusted.
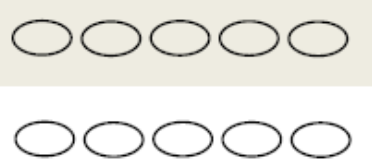

In La Pine, you can express different points of view in public conversations without fear or concern.

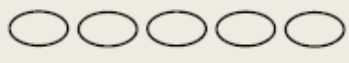

Most people in La Pine participate in community activities.

If there is a major fire in or near La Pine, people would come together to solve the problems.

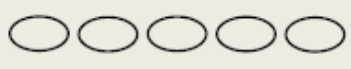

If there is a community event to assist people with becoming prepared for wildfire, most people will participate in some way.

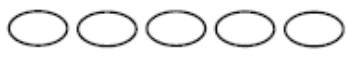

The people of La Pine have similar values.

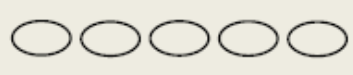

I feel like I have power and control over my life and property.

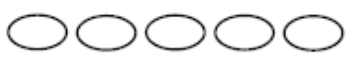

People in La Pine work together with government leaders for the benefit of the community.

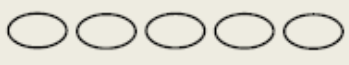

La Pine has a fire preparedness program with information that is readily available.

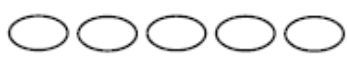

The people of La Pine prepare for the unexpected.

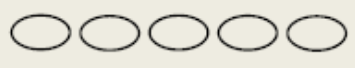

Most people in La Pine would attend public fire education and emergency preparedness presentations.

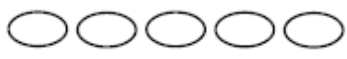

Local government agencies can be trusted.

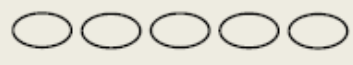

County government agencies can be trusted.

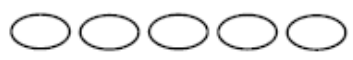

Oregon state government agencies can be trusted.

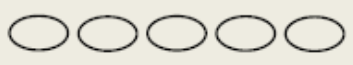

Federal government agencies can be trusted.

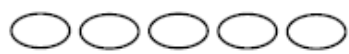


Figure A1.2: The roster of governmental activities information sources taken from the questionnaires.

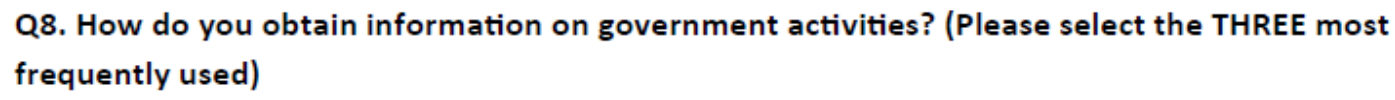

Political associations

Television

Community leaders

Internet 
Appendix 2, Methods and analysis for social capital and climate change regressions

Table A2.1 and A2.2 provide the results for the regression analysis investigating potential relationships that the social capital measures of governmental trust, collective action and solidarity (independent variables of interest) have on perspectives of climate change (Table A2.1) and then on local concerns for risk (Table A2.2). Each regression is performed using hierarchal multiple regression modeling. The initial model includes two demographic variables associated with climate change perspectives: age in years and gender (Knez et al 2013). Age is often negatively associated with concerns on climate change (Knez et al 2013, Newport 2014) and females have been shown to have a higher degree of concern for climate change in general (Knez et al 2013, McCright 2010).

In model 2 a dummy variable is added to test for a significant difference between the incorporated city of La Pine and the rural communities compiled for Greater Crescent. This variable is added as a dummy with 1 representing the incorporated city of La Pine.

In model 3 the social capital variables in question are added in to the regression, governmental trust, collective action and solidarity. These variables are indices generated from the Principal Component Analysis and reliability analyses discussed above.

Table A2.1. Hierarchical multiple regression analyses explaining climate change position for residents in La Pine and Greater Crescent using standardized regression coefficients.

\begin{tabular}{|c|c|c|c|}
\hline & Model 1 & Model 2 & Model 3 \\
\hline \multicolumn{4}{|c|}{ Socio-demographic control variables } \\
\hline Gender (Female $=1)$ & 0.04 & 0.04 & 0.03 \\
\hline Age & -0.12 & $-0.15^{\dagger}$ & $-0.16+$ \\
\hline \multicolumn{4}{|l|}{ Community } \\
\hline La Pine (La Pine residents= 1 ) & - & -0.11 & -0.11 \\
\hline \multicolumn{4}{|l|}{ Social Capital Measures } \\
\hline Network Ties Index & - & - & -0.07 \\
\hline Governmental Trust Index & - & - & $0.29 * * *$ \\
\hline Collective Action Index & - & - & 0.13 \\
\hline Solidarity Index & - & - & -0.13 \\
\hline$R^{2}$ & 0.02 & 0.03 & $0.13^{* *}$ \\
\hline Adjusted $\mathrm{R}^{2}$ & 0.01 & 0.01 & $0.08^{* *}$ \\
\hline $\mathrm{N}$ & 145 & 145 & 145 \\
\hline
\end{tabular}


Table A2.2. Hierarchical multiple regression analyses explaining concerns for local climate change risks for residents in La Pine and Greater Crescent using standardized regression coefficients.

\begin{tabular}{|c|c|c|c|}
\hline & Model 1 & Model 2 & Model 3 \\
\hline \multicolumn{4}{|c|}{ Socio-demographic control variables } \\
\hline Gender (Female $=1)$ & -0.10 & -0.09 & -0.12 \\
\hline Age & -0.11 & -0.13 & -0.05 \\
\hline \multicolumn{4}{|l|}{ Community } \\
\hline La Pine (La Pine residents= 1 ) & - & $-0.18+$ & $-0.19+$ \\
\hline \multicolumn{4}{|l|}{ Social Capital Measures } \\
\hline Network Ties Index & - & - & 0.11 \\
\hline Governmental Trust Index & - & - & 0.16 \\
\hline Collective Action Index & - & - & $0.31 * *$ \\
\hline Solidarity Index & - & - & $-0.21+$ \\
\hline$R^{2}$ & 0.02 & 0.05 & $0.17^{*}$ \\
\hline Adjusted $\mathrm{R}^{2}$ & -0.00 & 0.02 & $0.11^{*}$ \\
\hline $\mathrm{N}$ & 98 & 98 & 98 \\
\hline
\end{tabular}

The results of the both hierarchal regressions for climate change perspectives and concerns for local risks are addressed below. It is important to note that the sample size changes for each regression with $\mathrm{n}=143$ in the first regression on climate change perspectives (Table A2.1) to $n=98$ in the second regression on concerns for local risks. This is the result of the respondents question specific response rates and by the "unsure" option available on the local concerns questions which reduced the number of available samples for the regressions.

The results found for the demographic variables of Gender and Age in both regressions on Climate change perspectives (Table A2.1) and on concerns for local impacts (Table A2.2) in model 1 show no statistical effect on the dependent variables which is counter to expectations. When community is added in Model 2 we again see no statistical relationship to the dependent variables except for a very slight indicator estimate of $b=-0.18(p \leq 0.10)$ when community is added to the model on concerns for local impact yet the $\mathrm{R}^{2}$ and Adjusted $\mathrm{R}^{2}$ show that the model is insignificant. Yet when we add the social capital variables in Model 3 for both regressions we see statistical significance in at least one social capital variable variables and the $R^{2}$ and Adjusted $R^{2}$ rise in value and show statistical significance.

In the first regression on climate change perspectives (Table A2.1), the variable Governmental Trust shows a positive impact on residents perspectives of climate change in general. This Model (Model 3) also shows an increase in the $R^{2}$ from 0.02 and 0.03 in Models 1 and 2 respectively to 0.13 along with a statistical significance of $p \leq 0.01$. In the second regression on concerns for local impacts the social capital index for collective Action shows a positive statistically significant impact on the dependent variable $(b=0.31, p \leq 0.01)$. Furthermore Model 3 has an $R^{2}$ change from 0.02 and 0.05 from Models 1 and 2 to an $R^{2}$ of 0.10 with the addition of statistical significance at $p \leq 0.05$. 
These results are not intended for to be predictive, but suggest that there is a positive impact made by trust in governmental institutions on perspectives on climate change and a positive effect of perceptions of a community's collective action potential with concerns for local risks. Furthermore, there is an indication that a potentially negative effect of a residents sense of community solidarity on concerns for local risks in these communities. This indicates that social capital measures should encouraged in further community-based climate change research. More specifically, trust values in various governmental levels and agencies should be taken seriously for addressing climate change adaptation in these communities and that those who perceive the community as a collaborative and collective unit are much more likely to have the concerns on localized climate changes risks. 
Appendix 3: Governmental activities information sources methods and analyses.

As the paper has indicated, the city of La Pine and the Greater Crescent communities of Oregon are socioeconomically and environmentally linked to the federal and state public forests that surround them. Therefore public policy and actions by the federal government and state legislators and the agencies that administer the lands have an effect on these communities especially when it comes to the funding and management of the forests to address wildfires and future management and planning for climate change. As we have seen in the paper and in Appendix 2, the expressed social capital measure of governmental trust has an effect on how residents in these communities perceive climate change. It does not however seem to impact the concerns the residents have on localized risks. This can be problematic in the sense that global climate change is not what these communities need to adapt to as much as the local manifestations. Bridging the links between the global scale and localized scale of climate change and addressing those local risks in the public forests may take local governmental agencies and collaborative efforts with the residents in the communities to address.

In order to gain insight into the residents means of collecting information on governmental activities which could include but is not limited to the direct and indirect policies and actions on addressing wildfire and regional climate change in local forests we asked "How do you obtain information on governmental activities" and to select three. This question was followed by a roster of 14 possible sources:

Personal/social relations, community bulletin board, local markets, membership groups/associations, business/ work associates, political associations, community leaders, governmental employees/agents, non-governmental organizations, local newspaper, state or national newspaper, radio, television, and internet. The interest in relation to this study is to find the most utilized source types and see if a correlation can be made to governmental trust, collective action and community solidarity, as we are now aware that governmental trust has a positive relationship on climate change perspectives and residents with higher perceptions of collective action for the community have a more concerns for local risks.

The data was collected from the respondents and incorporated into UCINET in community case files for analysis. To identify the most common sources used by the residents of La Pine and residents of Greater Crescent two-mode normalized degree centrality analysis was run for each community. The scores from UCINET are presented in Table A3.1 for both communities. The three highest centrality scores and the ones most frequently used in La Pine are television, local newspaper and internet (centrality scores 0.494, 0.468 and 0.429 respectively). The three highest scores for Greater Crescent respondents were also television and the local newspaper with centrality scores of 0.431 followed by personal/social relationships with a score of 0.353 . This does show some consistency with the social network analysis and social capital literature, larger communities are more likely to maintain impersonal and mass media links to information sources while smaller communities are more likely to maintain a degree of personal social ties as a source of information (Richardson et al 1979)

Table A3.1: Normalized two-mode degree centrality analysis of residents in both Greater Crescent and La Pine on the sources they use for governmental activities information.

$\begin{array}{lll}\text { Media Agent: } & \text { Greater Crescent } & \text { La Pine } \\ \text { Personal/Social Relations } & 0.353 & 0.286 \\ \text { Community Bulletin Boards } & 0.275 & 0.091 \\ \text { Local Markets } & 0.059 & 0.065 \\ \text { Membership Groups/Association } & 0.108 & 0.143 \\ \text { Business/Work Associates } & 0.118 & 0.169 \\ \text { Political Associations } & 0.078 & 0.169 \\ \text { Community Leaders } & 0.127 & 0.182 \\ \text { Governmental Employee/Agent } & 0.157 & 0.104\end{array}$




$\begin{array}{lll}\text { Non-Governmental Organization } & 0.020 & 0.078 \\ \text { Local Newspaper } & 0.431 & 0.468 \\ \text { State/National Newspaper } & 0.069 & 0.065 \\ \text { Radio } & 0.284 & 0.195 \\ \text { Television } & 0.431 & 0.494 \\ \text { Internet } & 0.333 & 0.429\end{array}$

Knowing which information sources the residents of the communities' use most often allows agencies and institutions to use specific media sources and have some degree of confidence on if and how information is likely to transfer from resident to resident. The interest here is in whether or not these sources of information have an impact on expressive outcomes of social capital such as governmental trust, collective action and solidarity in the communities. To assess any relationship information sources have to social capital measures of interest in this study we used the respondents self-reporting on the roster and their index scores for governmental trust and collective action. This analysis was run on split data files for each community in SPSS and La Pines sample had $n=72$ while Greater Crescent had sample $\mathrm{n}=93$. Disparity in samples comes from respondent's selective question response rate and from the removal of cases in which respondents did not include 3 sources or responded with more than 3 selected sources.

For the results of the analysis on bivariate correlations between governmental information sources and the two expressive social capital variables governmental trust and collective action, the results for both communities were not as expected. For La Pine (Table A3.2), only two information sources have a statistically significant correlation to social capital variables and both are correlated to governmental trust. The most noteworthy is the internet, which is one of the top three information sources used in the La Pine. The internet has a negative correlation to governmental trust $(\mathrm{r}=-0.30)$ and is statistically significant at $\mathrm{p} \leq$ 0.05 . The second information source with a statistically significant correlation $(p \leq 0.05)$ is the radio. The radio is not one of the top three information sources used in La Pine but it is noteworthy that the radio shares with the internet a negative correlation to governmental trust $(r=-0.28)$.

Table A3.2: Bivariate Pearson Correlations for sources used to acquire governmental information and the relationship these sources have on governmental trust and collaborative action for La Pine $(\mathrm{N}=72)$.

$\begin{array}{lll} & \text { Governmental Trust } & \text { Community's Collective Action } \\ \text { Personal/Social Relations } & 0.00 & 0.07 \\ \text { Community Bulletin Boards } & 0.09 & 0.02 \\ \text { Local Markets } & 0.16 & 0.01 \\ \text { Membership Groups/Association } & 0.05 & 0.08 \\ \text { Business/Work Associates } & 0.01 & -0.01 \\ \text { Political Associations } & -0.09 & -0.20 \\ \text { Community Leaders } & 0.23 & -0.13 \\ \text { Governmental Employee/Agent } & 0.08 & -0.08 \\ \text { Non-Governmental Organization } & 0.02 & 0.15 \\ \text { Local Newspaper }_{\text {State/National Newspaper }}{ }^{2} & -0.07 & -0.19 \\ \text { Radio }_{\text {Television }}{ }^{1} & 0.04 & .00 \\ \text { Internet }^{3} & -0.28^{*} & -0.05 \\ & -0.07 & 0.03 \\ & -0.30^{*} & -0.07\end{array}$


Note: Superscript values on information sources denote the three most central sources; ${ }^{*} \mathrm{p} \leq 0.05$

For the Bivariate Pearson Correlations between governmental information sources and governmental trust and collective action in Greater Crescent, the results show nothing of significance for this study. The results (see Table A3.3) show that only one information source has any statistically significant correlation to the social capital variables: non-governmental organizations. Non-governmental organizations are not a central information source to Greater Crescent but they do have a negative correlation to both governmental trust and to collective action, $r=-0.24$ and $r=-0.22$ respectively.

Table A3.3: Bivariate Pearson Correlations for sources used to acquire governmental information and the relationship these sources have on governmental trust and collaborative action for Greater Crescent $(\mathrm{N}=93)$.

Personal and Social Relations ${ }^{3}$

Community Bulletin Boards

Local Markets

Membership Groups and Association

Business and Work Associates

Political Associations

Community Leaders

Governmental Employee/Agent

Non-Governmental Organization

Local Newspaper

State/National Newspaper ${ }^{1 \text { and } 2}$

Radio

Television $^{1}$ and 2

Internet
Governmental Trust

$-0.15$

$-0.11$

$-0.02$

0.13

$-0.00$

0.01

0.01

0.13

$-0.24 *$

0.03

0.15

0.03

0.09

0.00
Community's Collective

Action

$-0.15$

$-0.17$

0.19

0.01

0.03

$-0.04$

0.05

$-0.01$

$-0.22 *$

$-0.09$

$-0.10$

0.01

0.05

0.04

Note: Superscript values on information sources denote the three most central sources; ${ }^{*} \mathrm{p} \leq 0.05$ In the research framework, the third research question asked "Is there a correlation between a community's information sources on governmental activities (their instrumental social capital) and the measures of solidarity, collective action potential, and governmental trust (their expressive social capital)?". The hypotheses suggested that there would be correlations between information sources and expressive social capital measures and that mass media sources would maintain negative correlations to government. The results show that only three information sources correlate to the social capital measures and all of them, mass media (radio and internet) as well as institutional (non-governmental organizations) correlate to governmental trust negatively. 